\title{
Integrated Localization Theory of Translation Studies ${ }^{1}$
}

\author{
Mehmet Cem ODACIOĞLU* \\ Translation Studies Department, Bartın University, Turkey
}

Corresponding Author: Mehmet Cem ODACIOĞLU, E-mail: cemodacioglu@bartin.edu.tr

\author{
ARTICLE INFO \\ Article history \\ Received: July 07, 2017 \\ Accepted: September 12, 2017 \\ Published: October 31, 2017 \\ Volume: 5 Issue: 4 \\ Advance access: August 2017 \\ Conflicts of interest: None \\ Funding: None \\ Keywords: \\ Integrated localization theory, \\ Localization industry, \\ Localization, \\ Informatics and communication tech- \\ nologies, \\ Localization paradigm, \\ Localization theory
}

\begin{abstract}
As with every other discipline, Informatics and Communication Technologies have also begun to affect translation studies. In this context, this study covers a part of my doctoral thesis written on the topic and is based on the debate about whether existing translation theories need to be revised in accordance with current conditions. The study contends that, as with other translation theories developed for specialized translation areas, the 'localization industry' that initially became popular in the late 1980s and for which attempts have been made, by those conducting this study and some translation scholars, to include it under the umbrella of translation studies in the belief that it would be a gain for translation studies, requires a new translation theory. Accordingly, this study intends to build a bridge between translation studies and the theory of localization, which has emerged as an industrial discourse. A theoretical proposal called the 'integrated localization theory' of translation studies has also been proposed in the study. Furthermore, it is considered that this theoretical proposal will not discredit the existing translation theories that have emerged in different periods and show the characteristics of paradigms, but will instead combine and harmonize them. With this approach, localization may even be transformed into one of the new paradigms of translation studies.
\end{abstract}

\section{INTRODUCTION}

Since the second half of the $20^{\text {th }}$ century, translation has developed from being a mere activity into the discipline of translation studies and, as a result of the theories and scientific theoretical studies developed by academics, has gained the status of an interdisciplinary science. In order for the scientific areas to make progress and develop new paradigms ${ }^{2}$, they should be open to innovative approaches and proposals. As stated by Vermeer, in order for theories to develop new results in line with innovative approaches, and to let the next generation of scientists benefit from these, they may need to be reinterpreted (see Vermeer, 1994: 9, cf. Öner, 2006; cf. Odacığlu, 2016; Odacığlu, 2017; Odacığlu, 2017). This need for reinterpretation is considered to be as a consequence of the fact that today's translation community fails to explain the problems it faces with the existing theories ${ }^{3}$.

While most of the translation theories that have been developed so far address literary translation (see Descriptive Translation Studies, Polysystem Theory, Rewriting, etc) ${ }^{4}$, the theories developed for the area of technical translation are recognized as functional translation theories. The pioneers of functional translation theories include Vermeer's
Skopos Theory and Mänttari's Theory of Translatorial Action. Meanwhile, it is thought that some changes have occurred in the application of these theories to the localization industry, due to current conditions. Accordingly, translation studies and the profession of translation are assumed to be areas equipped with different dynamics in line with the digital revolution, and thus existing translation theories can be insufficient for explaining the recent developments (Odacıŏlu, 2016: 151-152).

It is accepted that the Skopos Theory and Mänttari's Theory of Translatorial Action are prospective theories advocating a target-oriented approach. Consequently, these theories attach importance to the expectations of the target group, which is more relevant for the category of cultural transformation/turn, rather than sentence-based approaches and the seeking of (linguistic) equivalence, which is generally analyzed under linguistic transformation/turn. As a result, equivalence can be reduced to a special case, as stated by Vermeer. Therefore, according to these theories, the prime objective of a translator is not to seek equivalence but to produce a translated text by making translation decisions that are most relevant for the target audience. However, it seems that the localization industry has compelled the translator to 
revert to seeking equivalence because, during the phase of localization, translators benefiting from translation technology tools are in the position of translating phases without having a sense of the whole text. In these circumstances, some changes are likely to happen in the application of the Skopos Theory and the Theory of Translatorial Action ${ }^{5}$.

According to Odacioğlu (2016: 153-154), in this context the group targeted by the localization industry is not the general public, as not all the localized products can address everyone. That is why small target groups are addressed by the localization industry. Accordingly, it can be said that the Skopos Theory and the Theory of Translatorial Action, which are criticized for being unspecific, address a partial group in the localization industry. Then again, if the intention is to theorize localization, other theoretical approaches in addition to these two approaches also need to be included in the localization works, and a harmonizing (see Ruano, 2006) approach for these theories to function side by side needs to be adopted ${ }^{6}$.

\section{A BRIEF OVERVIEW OF LOCALIZATION INDUSTRY}

If considered as an industrial discourse, localization is the full adaptation process of a product or service to another marketplace where it will be sold and used (see Anastasio and Schäler, 2010: 2 http://www.d-anastasiou.com/ Publications/Syntheses.pdf). On the other hand, according to Cyr, localization is the process of adapting the products, services and related content to different cultures and cultural choices ${ }^{7}$. Localization process is not only about translating texts. In addition, the figures, colors and buttons, for example, which guide the users, may also need to be adapted for the new audience (target group/local group) (Cyr, 2003: 2).

The localization industry first became popular in the 1990 s in the field of software localization ${ }^{8}$. In addition to this, the concept of website localization developed in line with the wider use of the Internet, and various forms of game localization have emerged in line with the remarkable levels reached by computer technologies and graphic processors, especially since the 2000s. According to Canım Alkan:

"Until the early 1980s, American software producers were not in need of internationalized and localized products. Meanwhile, the 1980s also witnessed the widespread use of desktop computers among ordinary people, who were not experts in computer technology. Moreover, American computer hardware and software companies also launched new initiatives during this period. For example, Sun Microsystems and Microsoft started operating in Europe in 1983 and 1979, respectively. In line with all these developments, some changes needed to be made to the products in order to meet the users' expectations. As also stated by Jeanty (1997), the computer software localization industry emerged in the mid-1980s with the aim of enabling the computer industry to expand its presence in the world market, by amending the products to address the languages and related customs of target markets" (Canım-Alkan, 2013: 6-7).

Likewise, the localization industry, which rapidly began to cover various types of digital text in addition to computer software and that has gained a significant share in the translation market, considers translation as a step toward localization (cf. Esselink, 2000; Pym, 2010). Although this shows that the act of translation appears to have become of secondary importance, a majority of translation scholars claim that localization is a specialized area of translation (see Pym, 2004; 2010). This may be because the act of translation is not the sole responsibility of the translator, as a bicultural expert, especially in the digital era. In addition to having a good command of both languages and cultures, the translator should also have a good command of technology and undertake various missions in localization projects - in addition to the act of translation - by assuming the role of a kind of technical communicator (see Pym, 2014). In other words, in addition to carrying out the act of translation, the translator can also take part in localization projects as a language engineer, localization engineer, project manager, technical writer, editor or post-editor (see Pym, 2012). And this may enable localization to become one of the various different areas of expertise under translation studies.

According to Esselink, the steps that should be followed during a localization project are as follows:

1. The phase of project management,

2. The translation and software engineering processes,

3. The translation of online help and web content files, and related processes that require engineering knowledge,

4. The translation of computer based training components and multimedia content,

5. The conducting of localized software, web application, or game functionality tests (see Esselink, 2000: 4).

\section{INTRODUCTION TO THE 'INTEGRATED' LOCALIZATION THEORY OF TRANSLATION STUDIES}

In order for an area of science to progress and solve newly emerging problems in this area, various different approaches and paradigms are required. In addition, new alternatives are also sought when the alternatives, which were previously developed to solve an old problem, cannot meet the requirements of the age. This is a prerequisite for preventing areas of science from merely transforming into an area of knowledge. Then again, due to it being open to progress, the field of translation studies has become an interdisciplinary, and even transdisciplinary science (cf. Şan, 2013, cf. Yazıc1, 2011, cf. Odacioğlu, 2016). Accordingly, a theory under the name of 'integrated localization theory of translation studies' has been proposed for the study in question.

\subsection{The Word 'Integrated'}

Although the word 'integrated' is defined in the official web site of the Turkish Language Institution (TDK) as 'some- 
thing that has integrated with another thing', the online Cambridge dictionary explains the same concept (to integrate) as combining two or more things in order to become more effective ${ }^{9}$.

\subsection{1. 'Integrated' localization theory}

It is acknowledged that various theories relating to translation studies have emerged over different periods, and this is why they are examined under the titles of linguistic, cultural, social and technological turns (cf. Snell-Hornby, 2006). In addition, most of the theories of translation, especially those developed since the 1980s have been in the field of literary translation. For example, while Zohar's polysystem theory, Toury's descriptive translation studies and Lefevere's theory of rewriting, among others, are about literary translation, the functionalist theories of translation have been developed primarily for the area of technical translation. However, the line of reasoning proposed by Vermeer, Reiss (1984), and Holz Mänttäri (1984) claimed that functionalist theories could also be applied to texts as well as those technically translated. Yet, the functionalist theories of translation (Skopos Theory and the Theory of Translatorial Action) have been developed based on the assertion that they are general theories of translation. However, sometimes, even these theories may not go beyond providing professional translator candidates with a superior standpoint (cf. Odacıŏlu, 2016; Odacıŏglu 2017).

The 'integrated localization theory' proposed in this study, on the other hand, advocates a harmonizing approach among translation theories, by combining the approaches that have emerged as a result of linguistic, cultural and technological transformation/turn. In other words, linguistic, cultural and technological transformation/turn operate together within the said theory (also see Odacioğlu, 2016; 2017). Odacioğlu explains this more comprehensively and from different perspectives, as follows:

"Translation practice in the field of localization operates differently from classical translation practice. This is because, although in classical translation there is a bilateral relation between the source and target texts and most of the time a horizontal translation method is adopted, in the translation practice used in localization, the role of source text is replaced by internationalization, and as a rule vertical translation method has begun to be adopted, in the same way as linguistic translation approaches. The reason behind this is the use of translation technology tools and localization tools in the translation practice used in localization. Consequently, translation practice has become integrated with technology. In addition, while the localization process is going on, the expert translator is assisted by a team of players coming from different disciplines and areas of science. Team members have become integrated to the [localization] process, and although indirectly, to the translation practice and localization project by using various technological tools (see computer programming, computer engineering, graphic design tools, translation management systems, project management systems, etc.). In addition to these, the translator may also assume different roles (e.g. project management, post-editing, marketing consultancy, localization engineering, language engineering, etc.) in the localization process, and use his 'expertise in translation practice' in integration with different fields. Thus, translators may also be termed localizer or localization expert. This gives the impression that the role of translators in the localization team is not only translation. In other words, the scope of the translation concept may be expanded in accordance with the respective field. Moreover, both target-oriented and linguistic approaches are used together in the integrated localization theory ${ }^{10}$. In other words, functionalist translation theories, which emphasize target-orientation, discredit the concept of equivalence to a specific level and argue that the main and first priority of the act of translation is to make translation in accordance with the expectations of the target audience, rather than ensuring equivalence. However, as the translation practice in the field of localization has reverted to linguistic approaches, a kind of equivalence has again begun to be implemented. This equivalence is artificial (see Pym, 2001; 2010; 2014). Although the translator seems to be restricted here, asking certain questions (who is the target audience of the translated product, etc.) before starting the localization, and making reference to cultural adaptations after the completion of translation practice, in the post-editing phase and even in the testing phase, making the product and its content-related components tailored to the milieu. In other words, the product is being localized in a way that is target-oriented. In fact, what lies at the core of localization are the expectations of the target group or the locale" (Odacıoglu, 2016: 163-165; Odacıoğlu, 2017:246-252).

Regarding his theoretical trial within TS, Odacıoğlu also advocates that one of the reasons for preferring the concept of localization theory for a theoretical trial is to ensure that localization theory is examined under the umbrella of the theories of translation studies, and is positioned within this discipline. In this regard, integrated localization theory can also be examined in a way that is integrated with the theories of translation studies or with the translation studies themselves. In addition, the fact that functionalist theories, such as linguistic transfer (linguistic translation theories), Skopos Theory, and the Theory of Translatorial Action are handled together within the context of localization theory, their integrated use with technological (digital) media (computerized tools, software, etc.), as well as the other factors mentioned above, may give rise to the theory [concept] of integrated localization theory (emphasis intentional). Thus, the translator candidates, who wish to specialize in this field, need to use the two different paradigms in harmony; in other words, the translation approaches based on linguistic transfer and target-oriented translation theories that have emerged over time. In addition, as experts competent in translation technology tools, they should also assume different roles in addition to translation practice. Accordingly, 
integrated localization theory may find a field of practice for itself. It is deemed that, in order to establish an infrastructure for this theoretical trial, the curricula of the programs on translation studies, as well as the translation and interpretation programs, need to be updated and the required equipment should be provided. Finally, those assuming the role of translator and the actors and localizers taking responsibility as part of the team, who intend to complete the translation practice expeditiously by assisting the translator and using this productivity increase to ensure that the product is simultaneously localized into several languages, serve as a gear in the operation of the process by integrating with each other through network path technologies and other technical tools. If one of the gears breaks away from

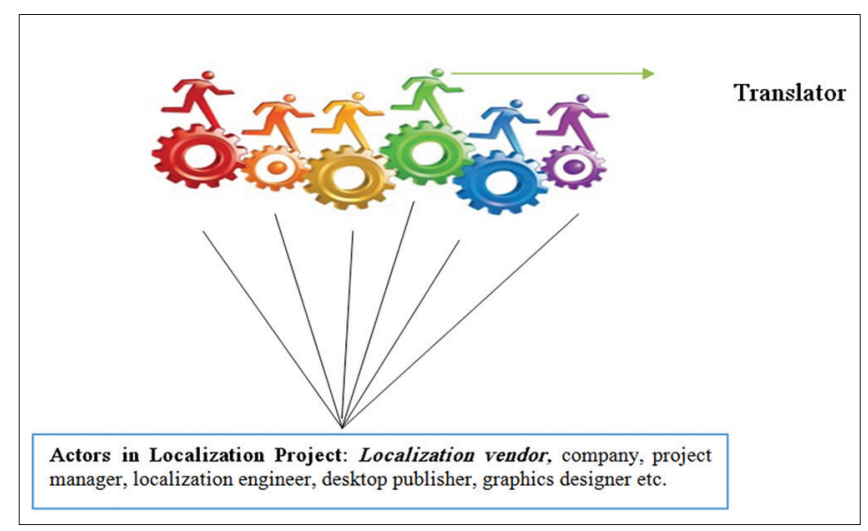

Figure 1: Gears in integrated localization process ${ }^{11}$ the others, or if the act of translation, which is at the core of localization, also acts separately from the other gears, a failure may occur in the localization process. (Odacioğlu, 2016: 163-165; Odacıoglu, 2017:246-252).

When explaining the integrated localization theory, Odacığlu also described the gears in the localization process as follows:

As may be seen in the figure, one of the players at the very core of localization is the translator. This is because a localization project cannot be completed without the act of translation. Moreover, as is frequently highlighted, in addition to the act of translation, the translator also has other roles in the process. Thus, they are one of the experts who play a central role.

When proposing the integrated localization theory' of translation studies, Odacığlu also proposed a new map of translation studies. This is because, according to him, Holmes' map, which is divided into two areas, namely pure and applied, has some shortcomings and is criticized accordingly ${ }^{12}$. Moreover, some problems and disconnections may occur when forming a bridge between the pure and applied areas. If localization were to be placed in this map as a branch of translation studies, it would best fit within the applied branch of translation studies. In contrast, Odacioğlu proposes a third title namely, Regenerative Theories of Translation, for the category encompassing the general and partial theories of translation, which comprise the pure area. The reason behind this is that the word regenerative, which embodies the meanings of innovative and renova-

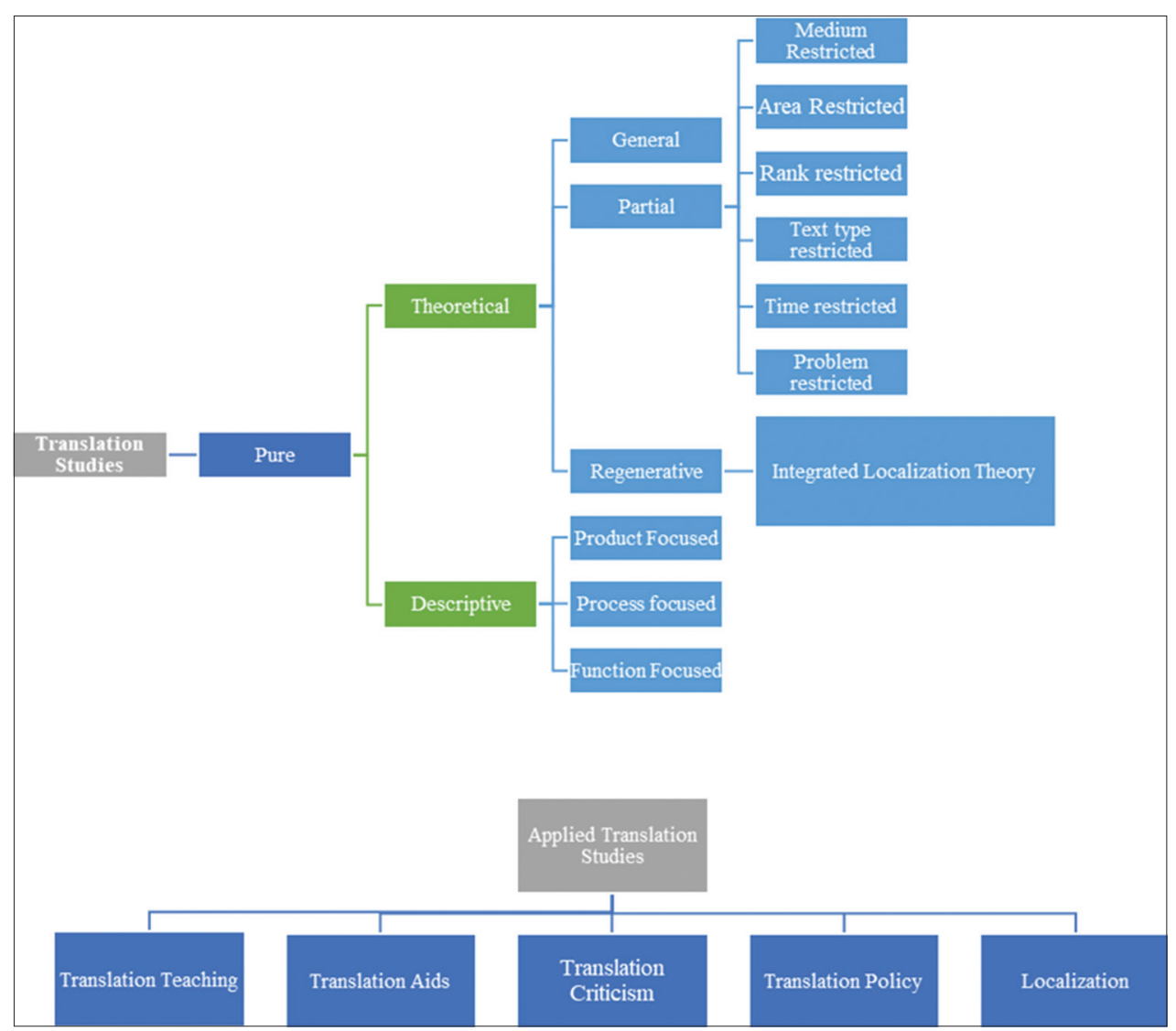

Figure 2: Suggestions of a New Translation Studies Map ${ }^{13}$ 
tor, is capable of covering dynamic areas such as the area of localization. Localization is a continuously developing industrial area, which is constantly evolving. Accordingly, if this area is to be theorized under the umbrella of translation studies, the category within which it would best fit is the regenerative theories of translation. Thus, provided that translation scholars adopt the integrated localization theory, it should be covered by opening a new category entitled regenerative theories of translation, rather than by being added to the general and partial categories (see Odacioğlu 2016 and 2017). The figure, as revised by Odacioğlu, is given below:

\section{CONCLUSION}

As a new discipline, translation studies embodies an interdisciplinary nature, and has the potential to constantly evolve from a scientific perspective. Furthermore, in order to pursue this potential, new forms of text and areas should be examined under the umbrella of translation studies, and even new theories of translation should be developed for these texts. Within this framework, this study includes a theory-based trial. In addition, a concept, namely the integrated localization theory, which integrates - or in other words harmonizes - linguistic, technical and technological cycles with each other, has been proposed by accepting localization as an area of expertise. Localization is a fast growing area, which may in time also cover various other forms of text. Therefore, by dealing with this area separately from translation studies, or examining translation as a step within it, it is not a gain but a loss for translation studies.

In this regard, different conceptual studies, proposals and approaches, which will cover the issue of localization under the umbrella of translation studies, resembling the one used in this study, are required ${ }^{14}$. This conceptual study, the aim of which is to position localization under the umbrella of translation studies; the theoretization studies in this area, especially by Pym, and the constant increase in the number of localization related articles written by translation scholars, as well as other related articles, may prevent the adoption of localization by translation scholars merely as an industrial discourse. By overcoming the disconnection between translation studies and localization, they may also prevent the localization industry from perceiving translation merely as a linguistic step. In addition, by increasing the number of conferences and events, held with the participation of employees working within the industry, as well as translation theorists, and inviting translation academics to localization conferences, or inviting people from the industry to scientific conferences, is important in terms of developing harmonizing approaches. Accordingly, as stated by Pym, both the replacement of the role of source text by internationalization (see Pym, 2010), and the efforts of this study of concern and similar others to find a theory for localization through bilateral meetings between the industry and translation scholars could make localization one of the most dynamic paradigms of translation studies.

\section{END NOTES}

1 This study is the abstract of the integrated localization theory related chapter of the doctorate thesis titled 'Towards the Localization Paradigm of Translation Studies' (2016). In March 2017, Gece Kitaplığ1 Publishing House also published the said doctorate thesis with the same title. The study concerned is a dialectical essay. The author of this paper is also owes many thanks to his advisor, Assoc. Prof. Şaban KÖKTÜRK for his scientific contributions to my doctoral thesis.

2. Kuhn defines this concept as "universally recognized scientific achievements that for a time provide model problems and solutions for a community of practitioners" (Kuhn, 2006 65).

3 Cf. Ho, 2008

4 See Odacioğlu, 2016; 2017.

5 There are, however, some translation scholars who argue that these theories are appropriate for localization. One of them is Canım Alkan, who proposes using the word 'target group' instead of 'local' as a discourse of localization in order to make the functional translation theories appropriate for localization. Because the word 'local' is severely restricted by a combination of the language and country, it does not allow for flexibility. On the other hand, target group is a flexible concept representing the group of people that the employer would like to address. It can also be expanded or narrowed down in accordance with the goals and expectations of the employer (2013:59).

6 Also see: Köktürk, 2015.

7 Localization industry is mainly interested in digital texts, and content and components of digital products (operating manual, online help files, etc.).

8 http://tdk.gov.tr/index.php?option=com_gts\&arama=gts\&guid=TDK.GTS.596b6a0be79a84.62282209.

9 http://dictionary.cambridge.org/dictionary/english/integrate.

10 It is possible to see the traces of cultural/technological transformations/turns in this theory.

$11 \mathrm{http}: / / w w w . m e r d i y e e k e r . c o m . t r / h a n g i-s t r a t e j i-d a h a-d o-$ gru/see Odacioğlu, 2016; 2017.

12 See K. Dunne and E.Dunne, 2011: 2; Vandepitte, 2008, O’Hagan, 2013.

13 Odacıŏlu, 2016; Odacığlu; 2017; Munday, 2012.

14 For detailed information on the theoretical study, see the book titled Towards the Localization Paradigm of Translation Studies.

\section{REFERENCES}

Anastasiou, D. and SCHÄLER R. (2010),’Translating Vital Information: Localisation, Internationalisation, and Globalisation", http://www.d-anastasiou.com/Publications/ Syntheses.pdf p.1-10. Accesion Date: 04.01.2015.

Canim Alkan, S. (2013), Web Sitesi Yerelleştirmelerinde Bir Eyleyen olarak Çevirmenin Konumu: Türkiye Örneği, Doktora Tezi, İstanbul Üniversitesi Sosyal Bilimler Enstitüsü Çeviribilim Anabilim Dalı. 
Cyr, D. And Lew, R. (2003), "Emerging Challanges in the Software Localization Industry", Thunderbird International Bussiness Review, Vol: 45, No: 3, (Spring 2003), p. 337-358.

Dunne, K., J DUNNE, E. S. (2011), "Mapping Terra Incognita: Project Management in the Discipline of Translation Studies", Translation and Localization Project Managament, (ed Keiran J. Dunne ve Elena S. Dunne), John Benjanins Publishing Company, Amsterdam/Philadelphia, p. 1-14.

Esselink, B. (2000), A Practical Guide to Localization, John Benjamins Publishing Company, Amsterdam/Philadelphia.

Ho, G. (2008), Globalization and Translation: Towards a Paradigm Shift in Translation Studies, VDM Verlag Dr. Müller, Saarbrücken.

Holz-Mänttäri, J. (1984), Translatorisches Handeln Theorie und Methode (Translatorial Action: Theory and Method), Academia Scientiarum Fennica, Helsinki.

Köktürk, Ş. (2015), Uygulamalı Çeviribilim, Detay Yayınc1lık, Ankara.

Kuhn, T.S. (1962/2008), The Structure of Scientific Revolutions- Bilimsel Devrimlerin Yapısı (çev. Nilüfer Kuyaş), Kırmızı Yayınları, İstanbul.

Munday, J. (2012), Introducing Translation Studies Theories and Applications Third Edition, Routledge, London and New York.

Odacıŏlu, M. C. (2016), Çeviribilimde Yerelleştirme Paradigmasına Doğru, Doktora Tezi, Sakarya SBE, Sakarya.

Odacıŏlu, M. C. (2017), Çeviribilimde Yerelleştirme Paradigmasına Doğru, Doktora Tezi, Gece Kitaplığı, Ankara.

Odacıŏlu, M.C. (2017), "Çeviribilimde Paradigma ve Disiplinler Ötesilik Kavrami Üzerine” (forthcoming) (book chapter), Bartın University, Bartın.

O, hagan, M. (2013), “The Impact of New Technologies on Translation Studies: A technological Turn?" The Routlege Handbook of Translation Studies, (ed. Carmen Millán and Francesca Batrina), Routledge, London and New York, p. 503-517.

Öner, I.-B. (2006), "Yerelleştirmenin Tanımı", Varlık (ed. Enver Ercan), Varlık Yayınları, İstanbul, p. 33-35.

Pym, A. (2004), "Localization from the Perspective of Translation Studies: Overlaps in the Digital Divide", Scalla Conference, Katmandu.

Pym, A. (2012), "Translation Skill Sets in a Machine Translation Age",Intercultural Studies Group, Universitat Rovira i Virgili, Tarragona, Spain, p.1-17. http://usuaris tinet.cat/apym/on-line/training/2012_competence_pym. pdf Accession Date: 20.12. 2014

Pym, A. (2010), Exploring Translation Thoeries, Routledge, London and New York.

Ruano, M. R. (2006), "Conciliation of Disciplines and Paradigms: A Challenge and a Barrier of Future Directions in Translation Studies", Translation Studies at the Interface of Disciplines, (ed. João Ferreira Duarte, Alexandra Assis Rosa and Teresa Seruya), John Benjamins Publishing Company, Amsterdam and Philadelphia, p. 43-53.

Snell-Hornby, M. (2006), The Turns of Translation Studies,
John Benjamins Publishing Company, Amsterdam and Philadelphia.

Reiss, K. And Vermeer, H. J. (1984/2014), Grundlegung einer allgemeinen Translationstheorie (Towards a General Theory of Translation: Skopos Theories Explained) (translated by Christiane Nord), Routledge, London and New York.

Şan, F. (2014), “Disiplinlerarasılık Açısından bir Bilim Dalı Olarak Çeviri (Translation Studies in terms of Inter-disciplinarity)" (Doktora Tezi), Sakarya Üniversitesi Sosyal Bilimler Enstitüsü, Sakarya.

Yazici, M. (2011), Çeviribilimde Araştırma, Multilingual, İstanbul.

Vandepitte, S. (2008), "Remapping Translation Studies: Towards a Translation Studies Ontology", Meta Translator's Journal, vol: 53, no:3, p. 569-588

Vermeer, H. J, (1994), "Translation Today: Old and New Problems", Translation Studies: An Interdiscipline, (ed. Mary Snell-Hornby, Franz Pöchhacker and Klaus Kaindl), p. 3-16.

http://tdk.gov.tr/index.php?option=com_gts\&arama= gts\&guid=TDK.GTS.596b6a0be79a84.62282209 Accession: 16.07.2017.

http://dictionary.cambridge.org/dictionary/english/integrate Accession Date: 11.06. 2017.

http://www.merdiyeeker.com.tr/hangi-strateji-daha-dogru/ Accession Date: 16.07.2017.

Suggested Reading:

Bartrina, F. and ESPASA EE. (2005), “Audiovisual Translation”, Training for the New Millenium, (ed. Martha Tennet, John Benjamins Publishing Company, Amsterdam and Phiadelphia, p. 83-100.

Bernal Merıno, M.A. (2015), Translation and Localisation in Video Games: Making Entertainment Software Glob$a l$, Routledge, London and New York.

Canım Alkan, S (2008), Türkiye'de Çeviri Bürolarında Web Sitesi Yerelleştirmeleri ve Bu Süreçte Bilgi Teknolojilerinin Kullanımı, Yüksek Lisans Tezi, İstanbul Üniversitesi Sosyal Bilimler Enstitüsü Çeviribilim Anabilim Dalı.

Enríquez R. and Vanessa and AUSTERMUHL, F. (2003), "Translation, Localization and Technology-Current Developments" Speaking in Tongues: Language across Context and Users (ed. Luis Pérez Gonzáles), Universitat de la Valéncia, Spain, p. 225-248.

ESSELINK, B (2006), "The Evolution of Localization", Translation Technology and Its Teaching, (ed. Anthony Pym, Alexander Perekrestkenko, Bram Starink), Inter Cultural Studies Group, Universitat i Virgili, p. 21-29.

HOLMES, J. S (1972/2008), "The Name and Nature of Translation Studies" (ed. Lawrence Venuti), Routledge, London and New York, p. 172-185.

Jiménez Crespo, M.A. (2013), Translation and Web Localization, Routledge, London and New York

Koby, G. S and BAER B.J. (2003), "Task Based Instruction and the New Technology", Beyond the Ivory Tower, (ed. Brian James Baer and Geoffrey S.Koby), John Benjamins Publishing Company, Amsterdam/Philadelphia, p. 211-227. 
Kosaka, T. ve ITAGAKI M. (2003), "Building Curriculum for Japanese Localization Translators", Beyond the Ivory Tower, (ed. Brian James Baer and Geoffrey S.Koby), John Benjamins Publishing Company, Amsterdam/Philadelphia, p. 229-249.

Kuhn, T. S. (1962/2008), The Structure of Scientific Revolutions- Bilimsel Devrimlerin Yapısı (çev. Nilüfer Kuyaş), Kırmızı Yayınları, İstanbul.

Malmkjaer, K. (2013), "Where are We (From Holmes' map until now)", The Routlege Handbook of Translation Studies, (ed. Carmen Millán and Francesca Batrina), Routledge, London and New York, p. 31-44.

O'hagan, M. and MANGIRON C. (2013), Game Localization, John Benjamins Publishing Company, Amsterdam and Philadelphia.

Pym, A. (2010), "Tranlation Theory Today and Tomorrow Responses To Equivalence”, Translationwissen-
schaft-Stand und Perspektiven,(ed Edt. Law N. Zybatow), Peter Lang, Frankfurt, p. 1-14.

Pym, A. (2013), "Trannslation Technology and Translation Theory: Dialogue with Anthony Pym on Localization", Chinese Translators Journal, No 4, p.61-64.

Schäler, R. (2010) "Localization and Translation", Handbook of Translation Vol 1, (ed. Yves Gambier and Luc van Doorslaer), John Benjamins Publishing Company, Amsterdam/Philadelphia, p. 209-214.

Sin-Wa1, C. (2013), “Approaching Localization”, The Routlege Handbook of Translation Studies, (ed. Carmen Millán and Francesca Batrina), Routledge, London and New York, p. 347-362.

Sin Wa1, C. (2015), "The Development of Translation Technology" The Routledge Encylopedia of Translation Technology (ed. Chan-Sin Wai, Routledge), London and New York, p. 3-31. 